\title{
11. Legal obstacles for contingent valuation methods in environmental litigation
}

\author{
Brian D. Israel, Jean Martin, Kelly Smith \\ Fayne, and Lauren Daniel ${ }^{1}$
}

\section{INTRODUCTION}

Contingent valuation surveys, and other stated preference methods, are sometimes used by economists to solicit opinions from the public regarding the monetary value respondents place on the existence of natural resources, independent of the use of those resources. For example, economists may attempt to use surveys to measure how much the respondent values a particular natural resource, such as a bird species or habitat, even if he or she never uses or sees that resource.

For decades, economists, government officials, and others have debated whether such survey methods can accurately measure non-use values in natural resource damage ("NRD") cases. A central premise of this debate is the oft-repeated notion that contingent valuation and other similar methods are allowed by the NRD regulations and accepted by the courts. ${ }^{2}$ As we demonstrate below, this premise is inaccurate for several reasons.

This chapter provides a brief overview of the regulatory context for NRD claims and the potential role for stated preference survey valuation methods for non-use damages. We then provide an overview of court decisions associated with contingent valuation methods (both in the

1 Respectively, Partner, Arnold \& Porter Kaye Scholer, LLP; Senior Counsel, BP America, Inc.; Associate, Latham \& Watkins, LLP; Associate, Arnold \& Porter Kaye Scholer, LLP.

2 See, for example, Ohio v. U.S. Dep't of the Interior, 880 F.2d 432 (D.C. Cir. 1989); Montesinos, M. (1999), It May Be Silly, but It's an Answer: The Need to Accept Contingent Valuation Methodology in Natural Resource Damage Assessments, Ecology Law Quarterly, 26(48), 57-60 accessed December 10, 2016 at http://scholarship.law.berkeley.edu/cgi/viewcontent.cgi?article $=1601 \&$ context=elq; Unsworth, R.E. and T.B. Petersen (1997), "Primary methods for compensable value determination," Chapter 4 in A Manual for Conducting Natural Resource Damage Assessment: The Role of Economics, accessed December 10, 2016 at https:// www.fws.gov/policy/NRDAManualFull.pdf. 
NRD context and beyond), and clearly demonstrate that courts have not accepted contingent valuation methods nor are they likely to do so in the future. Next, we explain why the NRD regulations strongly disfavor these methods. Finally, we discuss the public policies that weigh against the use of stated preference surveys as a measure of non-use damages, and recommend that governmental agencies abandon these survey methods and instead focus their attention on determining the actual cost of activities necessary to restore and replace injured natural resources.

\section{NRD REGULATORY FRAMEWORK AND THE BASIS FOR NON-USE DAMAGES}

Pursuant to the Comprehensive Environmental Response, Compensation, and Liability Act of 1980 ("CERCLA") and the Oil Pollution Act of 1990 ("OPA"), federal, state and tribal governments (sometimes called "trustees") may seek compensation for natural resource damages resulting from the release of hazardous substances (covered by CERCLA) and petroleum (covered by OPA). ${ }^{3}$ As a general rule, these claims are intended to restore the natural environment to its baseline condition and compensate the public for the interim losses from the time the damage occurs until the time that restoration is complete.

Regulations promulgated under both CERCLA and OPA provide for compensation for the total value of natural resource injuries, including non-use damages. For example, regulations promulgated under OPA define "the total value of a natural resource or service [to] include[] the value individuals derive from direct use of the natural resource, for example, swimming, boating, hunting, or birdwatching, as well as the value individuals derive from knowing a natural resource will be available for future generations." ${ }^{4}$ The second type of value is commonly referred to as the existence, bequest, or "non-use" value of the resource, and it may exist even for people who have never used, or even seen, the injured resource. For example, a person could place some value in the knowledge that a natural resource exists in its uninjured condition and will be available for use in the future.

Regulations promulgated under CERCLA provide for a similar calculation of damages. Specifically, the CERCLA regulations state that NRD

342 U.S.C. $\$ 9607$ (a)(4)(C); 33 U.S.C. $\$ 2702(b)(2)(A)$.

415 C.F.R. $\$ 990.30$ [emphasis added]. The OPA regulations further define "value" to include "the maximum amount of. . money an individual is willing to give up [e.g., to pay] to obtain a specific good." 
"may also include. . the compensable value of all or a portion of the services lost to the public for the time period from the discharge or release until the attainment of the restoration, rehabilitation, replacement, and/or acquisition of equivalent of baseline."5 Guidance issued with the regulations explains that "compensable value" may include compensation for non-use values. ${ }^{6}$

\section{APPROACHES TO ESTIMATING NON-USE VALUE FOR NATURAL RESOURCE DAMAGES}

There are multiple approaches to estimating the non-use value of lost or injured natural resources in NRD cases. These approaches generally fall into two categories: (1) the restoration-based approach, which determines the restoration projects necessary to provide services or resources of a similar type and quality lost by the pollution event; or (2) the economic valuation approach, which assigns a dollar value to the loss using economic tools, principally survey-based mechanisms.

\section{Restoration-based Approach}

A restoration-based approach compensates for natural resource damages through a determination of the type and scale of projects needed to provide services or resources of a similar type and quality as those lost. By restoring a resource to its baseline condition (the condition it would be in if the contamination never occurred), the non-use values associated with the resource will also be restored. Additional restoration can also be provided to compensate the public for the interim loss of a resource while it is in an injured state, including use and non-use values. So, for example, in the case of a contaminated river, in addition to restoring

543 C.F.R. $\$ 11.80$. See also 15 C.F.R. $\$ 990.53$ (regulation that ties NRD assessments under OPA to the costs of, among other things, "compensatory restoration" - compensation for the "interim loss of natural resources and services pending recovery").

6 See, for example, Natural Resource Damage Assessments, 59 Fed. Reg. 23,098 (proposed May 4, 1994) (to be codified at 43 C.F.R. pt. 11) ("Under the March 25, 1994, final rule [for assessing NRD], the costs of restoring, rehabilitating, replacing, and/or acquiring the equivalent of the injured resources are the basic measure of damages; however, these costs are only one component of the damages that trustee officials may assess. Trustee officials also have the discretion to assess the value of the resource services that the public lost from the date of the release or discharge until completion of restoration, rehabilitation, replacement, and/or acquisition of equivalent resources. 59 FR 14283. The term 'compensable value' is used to encompass all of the lost public economic values, including both lost use values and lost nonuse values"), accessed December 10, 2016 at https://www.gpo.gov/fdsys/pkg/ FR-1994-05-04/html/94-10636.htm. 
the condition and stock level in the river to baseline, a responsible party might also be required to improve the ecological conditions in a nearby river or install new fishing access points to increase the number of future fishing trips beyond baseline. These above-baseline improvements, assuming they are properly calibrated, will compensate for both interim lost use and non-use values associated with the pollution event. Because it sometimes is not possible or feasible to provide identical resources and/ or services as those lost, the restoration-based approach will allow for the replacement or acquisition of similar resources. When similar but not identical resources are used to compensate for the loss, it is important to consider the correct scale of those actions that will make the environment and public whole.

\section{Contingent Valuation Methods}

As an alternative to the restoration approach described above, the government could seek to calculate non-use damages by using stated preference, or survey, valuation methods. There are several types of survey methods used by economists to estimate non-use value. One of the most common methods is contingent valuation ("CV"), which estimates the value people place on a resource by asking a representative sample of the population how much their household would be willing to pay for changes in the condition of the resource. As part of the survey, the respondents are provided a description of the resource being valued, the improvement to be made or harm to be prevented, a planned program by which the improvements or prevention will be accomplished, and a payment mechanism by which the hypothetical program will be funded. Typically, the respondent will be asked whether he or she would be willing to pay a specified dollar amount for the program. Survey responses are used to calculate the average maximum amount each household says it is willing to pay, and this amount is then multiplied by the purported number of affected households to obtain the alleged total non-use value of the injured natural resource. $^{7}$

7 A related method used to estimate both use and non-use values of natural resources is the total value equivalency method ("TVE"). TVE is another type of survey-based assessment that derives from "conjoint" studies, which are common in marketing. Instead of asking respondents what they would be willing to pay for a resource in a single program, TVE presents multiple scenarios that describe programs of different size, scope, duration, and cost, and asks respondents what they would be willing to pay for each scenario. See Israel, B.D. (2008), "Natural resource damages," in M. Gerrard (ed.), Environmental Law Practice Guide, $\S \$ 32 \mathrm{~B}-1,32 \mathrm{~B}-71-32 \mathrm{~B}-73$ (discussing problems with CV and conjoint studies in NRD litigation). 


\section{NO COURT HAS EVER RELIED UPON A CONTINGENT VALUATION STUDY IN AN NRD CASE}

As discussed below, both the OPA and CERCLA regulations provide the option (albeit as a last resort) of relying on CV and other stated preference survey methods to estimate non-use losses. And, in the abstract, courts have upheld these regulations, deferring to the agencies on the idea that stated preference methods should be among the tools available to trustees. ${ }^{8}$ Similarly, courts have occasionally found that CV studies may be presented in court if they meet standard tests for the admission of expert evidence. ${ }^{9}$ However, in no case has a court actually relied upon a CV or similar study in determining the value of damages in an NRD case. Furthermore, several courts have ruled that CV studies are so unreliable that they cannot even be admitted into evidence. Below are a few illustrative examples:

\section{United States v. Montrose}

United States v. Montrose Chemical Corp. of California ${ }^{10}$ is perhaps the best-known case involving a CV study. There, the federal and state governments sued various companies for natural resource damages caused by the insecticide ingredient DDT and PCBs at the Palos Verdes Shelf near Los Angeles. NOAA commissioned a group of leading economists to conduct a $\mathrm{CV}$ study assessing the amount of NRD, including non-use values. The study is considered one of the most expensive CV studies ever conducted. ${ }^{11}$ The Montrose survey presented respondents with a description of the injury to the natural resources (e.g., bald eagles, peregrine falcons, white croakers, and kelp bass) and then described two options for remediation. Respondents could choose a natural restoration process, which cost nothing and would take 50 years to restore the resources, or a remedial program to cap and contain the pollutants in place, and restore the resources around the capped area in five years. The survey assigned a per household tax cost for the program randomly among four values: $\$ 10, \$ 30, \$ 60$, and $\$ 120$. The conclusions based on

8 See Ohio, 880 F.2d at 476 (CERCLA); Gen. Elec. Co. v. U.S. Dep't of Commerce, 128 F.3d 767 (D.C. Cir. 1997) (OPA).

9 See, for example, Order denying ARCO's motion in limine regarding Montana's CV survey, Montana v. Atl. Richfield Co., No. 6:83-cv-00317 (D. Mont. Mar. 3, 1997), ECF No. 856.

10 No. 90-cv-3122 (C.D. Cal. 1990).

11 See Thompson, D.B. (2002), "Valuing the environment: Courts' struggles with natural resource damages," Environmental Law, 32(57), 78. 
the CV survey were that the interim lost value, which included passive or non-use use, from the release of DDT and PCBs amounted to \$575 million.

Defendants moved to exclude the CV study, arguing that the facts presented to respondents in the survey did not match the actual harms to natural resources at the Palos Verdes Shelf. ${ }^{12}$ For example, whereas the survey told respondents that peregrine falcons had not been able to hatch any eggs and were having reproductive problems along the South Coast but not elsewhere, the government's experts admitted in deposition that there was no evidence of impaired reproduction and that the falcons were actually increasing along the South Coast. The defendants pointed to similar inconsistencies in the survey representations about bald eagles, white croakers, and kelp bass. The defendants argued that the expert testimony therefore did not "fit" the facts and did not accurately describe the injuries that Trustees were trying to value.

In opposition to this motion, the government plaintiffs argued that the basic facts in the survey - that DDT came from the Montrose plant and mixed with PCBs to cause injury to fish and birds, preventing certain recreational fishing over an extended period of time - matched the facts of the case. The government argued that the CV study could provide a yardstick for measuring and determining compensatory damages, notwithstanding the above factual differences. The government reasoned that any inconsistencies between the description of injury in the survey, and the injuries proven at trial, should go to the weight of the evidence before the trier of fact, not to admissibility of the survey. In addition, the government planned to conduct a supplemental CV study to focus on injuries to eagles and fishing of the white croaker, which could be used to further assess damages at trial.

The court granted the defendants' motion in a ruling from the bench, preventing the trustees from introducing the results of the CV study into evidence in their case. ${ }^{13}$ The court similarly did not allow the government to submit its report regarding its supplemental CV study. ${ }^{14}$ The court did not reject $\mathrm{CV}$ methods in all circumstances, but its refusal to admit the

12 The defendants stated that they were not addressing all of the perceived problems with the CV study, which would have required a thorough review of the academic literature and deposition of the trustees' experts. See Memorandum of Points and Authori ies in Support of Defendants' Motion to Exclude Plaintiffs' Contingent Valuation Report and Testimony Based Thereon, Montrose, No. 90-cv-3122 (Mar. 6, 2000), ECF No. 1768. Accordingly, other potential problems with the CV study were not addressed by the parties or the court.

13 Transcript of Hearing at 17:20-18:1, Montrose, No. 90-cv-3122 (Apr. 17, 2000).

14 Id. at 18:3-9. 
studies into evidence has far reaching implications that tie back to many of the underlying concerns with CV methods. As the court in Montrose concluded, the trustees will have to prove that the injuries described in a $\mathrm{CV}$ survey are a close "fit" to the injuries that trustees seek to prove at trial. Even if it is a well-designed survey, there will always be information that is omitted or simplified in the survey narrative. Furthermore, given that the conditions of resources are changing over time (and in many cases improving), it will be difficult, if not impossible, for trustees to design a survey that accurately describes the type and scope of harm that remains to be proven at trial.

\section{Idaho v. Southern Refrigerated Transport Inc.}

In Idaho v. Southern Refrigerated Transport Inc., ${ }^{15}$ the U.S. District Court for the District of Idaho determined that the CV study put forward by the Trustees as evidence of non-use damages was unreliable. Following a pesticide spill in the Little Salmon River, the State of Idaho brought claims against the distributor and trucking company for damages caused to the steelhead fish population. The state relied on a CV study to estimate non-use damages. However, the study had been prepared for a regional power planning council for purposes that were not related to the litigation, and it asked respondents how much they were willing to pay on their power bills to double the runs of steelhead and salmon in the Columbia River Basin. The government argued that the study provided a conservative and useful estimate of the dollar value of these fish species.

The court rejected the use of the study, concluding that it would be "conjecture and speculation" to determine damages in this case based on the study. ${ }^{16}$ The court found that "the study fail[ed] to determine to any degree of certainty what value should be placed on these fish based on their existence value." 17 According to the court, the study looked at the value of doubling the number of steelhead in a large area (the entire Columbia River Basin), rather than at the value of losing a much smaller number of steelhead in a small part of the same area. Like the Montrose case, this decision indicates that it will be difficult, if not impossible, to develop a stated preference survey that accurately matches the type, location, and size of the injuries that trustees will ultimately seek to prove at trial.

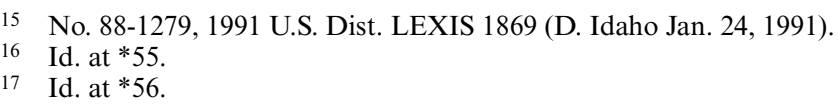




\section{American Trader spill litigation}

People v. Attransco, Inc., the NRD case related to the American Trader oil spill, proceeded to trial under California law (not CERCLA or OPA) in California state court. Surveys of actual consumer behavior were relied on heavily at trial, but CV surveys were not relied upon as affirmative evidence by either the plaintiffs or the defendants. The defendants did rely on a CV survey in rebutting the plaintiffs' estimate that each lost beach trip should be valued at $\$ 13.19$. In arguing that the plaintiffs' estimates were too high, the defendants relied upon a different survey that posed the following question: "Suppose the agency that manages this site started charging a daily admission fee of $\$ \mathrm{X}$ per person. The money from the admission fee will be used to maintain the site in the present condition, but there will be no improvements. Would you continue to use this site?" 18 The daily admission fee for each survey participant was one of ten randomly assigned amounts between \$1 and \$75. Most of those who responded said "no."

The jury was not persuaded by the CV survey. It assigned a daily beach trip value of $\$ 13.19$, a number based on the plaintiffs' estimate, without any effort to rely on the CV survey results. While we have no information about the reasons behind the jury's decision, it shows that juries, as well as judges, may question the validity of $\mathrm{CV}$ and other similar stated preference survey values and may prefer to use other methods to calculate damage to natural resources.

\section{CONTINGENT VALUATION METHODS HAVE ALSO NOT BEEN RELIED UPON IN NON-NRD CONTEXTS}

Similar to the NRD cases described above, CV methods have a poor record in other contexts as well. In the false advertising arena, for example, plaintiffs have tried to use CV methods to support alleged false advertising of the health benefits of "light" branded cigarettes. One such case is instructive. In Price v. Philip Morris, Inc., CV was used as the basis for the largest jury award in Illinois history, and, on appeal, the Illinois Supreme Court considered whether the jury's reliance on the $\mathrm{CV}$ was proper. ${ }^{19}$ A majority

18 Heyes, A. (2001), The Law and Economics of the Environment, Cheltenham, UK and Northampton, MA, USA: Edward Elgar Publishing, p. 340; original emphasis.

19848 N.E. 2 d 1 (Ill. 2005), cert. denied, 549 U.S. 1054 (2006). The plaintiffs' expert used the results of an Internet survey conducted by Knowledge Networks to calculate damages based on the CV method. The respondents were asked to assume that Marlboro Lights were more hazardous than full-flavor cigarettes and to imagine the existence of a Marlboro Light that was identical in all other respects to the current product, except that it was truly safer to smoke. The respondents were then asked to state how much of a discount would be required to cause them to purchase the more hazardous product if the safer version were actually 
of the Illinois Supreme Court voted to vacate the jury verdict and dismiss the plaintiffs' claims for reasons unrelated to $\mathrm{CV} .{ }^{20}$ However, a concurring opinion discussed the reliability of the $\mathrm{CV}$ in detail and found several problems. For example, according to the concurring opinion, the survey did not look at actual customer behavior in the marketplace and "did not measure or purport to measure how consumers would actually behave if, as is really the case, there is no truly healthier version." 21

Another arena in which plaintiffs have attempted to use CV to value their damages has been in cases involving the diminution of real property values. One such case was in the Western District of Louisiana arising from an oil spill in the Calcasieu Ship Channel in June 2006. ${ }^{22}$ There, Dr. Robert Simons conducted a CV survey to assess the drop in property values following a hypothetical oil spill to determine damages from the Calcasieu Ship Channel spill to property owners. In its motion to exclude Dr. Simons' testimony, the defendant Citgo criticized Dr. Simons for ignoring actual market data that showed no drop in property values. While the court allowed Dr. Simons to testify at trial, the jury returned a verdict in favor of Citgo.

A final example comes from Dr. Jerry Hausman's article "Contingent valuation: From dubious to hopeless," ${ }^{23}$ in which he reports on a CV survey utilized by plaintiffs in a copyright infringement case brought in the Australian Copyright Tribunal. In 2001, a change in Australian law defined retransmission of television programs as an infringement of copyright, requiring the cable TV companies to pay "equitable remuneration" to the copyright owners. The case was brought to determine the definition of "equitable remuneration," and the copyright owners' primary evidence was a CV study involving two parts.

The defendant cable TV companies, with the assistance of Dr. Hausman

available. Based on the answers to this question, the plaintiffs' expert calculated that class members, on average, would demand a $92.3 \%$ discount from the market price if they were to continue to purchase Marlboro Lights. Applying this discount to all purchases of Marlboro and Cambridge Lights during the relevant class periods, and calculating prejudgment interest at $5 \%$, non-compounded, the plaintiffs' expert concluded that the 1.14 million members of the class had suffered $\$ 7.1005$ billion in economic damages. Id. at 29 .

20 Id. at $50-51$.

21 Id. at 59.

22 See Citgo Petroleum Corporation's Motion to Exclude Opinion Testimony of Plaintiffs' Expert Robert Simons, Naquin v. Citgo Petroleum Corp., No. 2:09-cv-543, 2009 WL 2417500 (W.D. La. June 6, 2009) and Opposition to Defendant's Motion to Exclude Testimony of Robert Simons, Naquin, No. 2:09-cv-543, 2009 WL 2417506 (W.D. La. June 15, 2009) and Naquin's sister cases, Dartez v. Citgo Petroleum Corp., No. 2:09-cv-525, and Boullion v. Citgo Petroleum Corp., No. 2:09-cv-518.

23 Hausman, J. (2012), "Contingent valuation: From dubious to hopeless," Journal of Economic Perspectives, 26(4), 43. 
and others, brought various challenges to the study, including that preferences in the study appeared to be irrationally unstable and that the willingness to pay for the bundle of goods did not add up to the sum of the willingness to pay for the component part of the bundle. These challenges proved effective, and the Tribunal explicitly disregarded the results of the CV survey, stating that "[c]ourts and tribunals must proceed on the basis of probative evidence, not speculation... We have such a level of doubt about the Survey that we attach no weight to it." 24

\section{CONTINGENT VALUATION METHODS ARE HIGHLY DISFAVORED BY THE NRD REGULATIONS}

Both the OPA and CERCLA regulations strongly favor use of the restoration-based approach to valuation of all NRD. The OPA regulations, for example, plainly require that the governmental trustees may proceed with an economic valuation approach (such as CV) only after a restoration approach has twice been determined to be inappropriate.

Under the OPA regulations, trustees are required to first consider a resource-to-resource approach or a service-to-service approach that will provide natural resources and/or services equal in quantity to those lost. Only if they make an affirmative determination that this approach is inappropriate - presumably because an equal quantity of resources or services is not available and cannot be developed - can the trustees consider compensating the loss through a scaling approach. ${ }^{25}$ Under a scaling approach, the trustees must measure the value of the loss, and identify the amount of replacement resources needed to provide the same value to the public. Damages are still measured by the cost of providing the public with the correct amount of resources and services. ${ }^{26}$ Finally, only if the trustees also find that work to value replacement resources and/or services cannot be performed in a reasonable time frame or at a reasonable cost (a second affirmative determination), can the trustees turn to a non-restoration approach such as contingent valuation. ${ }^{27}$

In short, a trustee assessing damages under OPA can estimate the total

24 Id. at 53.

25 15 C.F.R. $\$ 990.53$ (d)(3)(i) ("Where trustees have determined that neither resource-toresource nor service-to-service scaling is appropriate, trustees may use the valuation scaling approach").

26 Id. ("Under the valuation scaling approach, trustees determine the amount of natural resources and/or services that must be provided to produce the same value lost to the public").

2715 C.F.R. $\$ 990.53$ (d)(3)(ii) ("If, in the judgment of the trustees, valuation of the lost services is practicable, but valuation of the replacement natural resources and/or services cannot be performed within a reasonable time frame or at a reasonable cost, as determined 
value of an injured animal or an injured acre of habitat, and use that as the measure of damages only if the trustee finds that those resources cannot be restored or replaced with similar substitutes, and an alternative restoration scaling approach would be inefficient. The trustees must make each of these affirmative determinations before they can even commission a stated preference survey to measure non-use damages. ${ }^{28}$ If these two determinations have not been made, the NRD defendants will have a strong legal basis to reject not only the use of such studies in assessing damages but also claims to reimburse the trustees for the cost of implementing the studies as part of the reasonable costs of a damages assessment. ${ }^{29}$

The approach to valuation in the CERCLA regulations has a more complex history. The initial regulations have seen various court challenges and amendments since they were first promulgated by the Department of the Interior (DOI) in 1986. In all versions of these rules, economic valuation techniques like CV and TVE are only available to measure interim losses, that is, those losses occurring during the time it takes to restore the resources and/or services lost to baseline (sometimes called "compensatory damages"). Unlike the OPA rules, however, some prior versions of the CERCLA rules arguably required trustees to ascertain a dollar value of interim loss damages through the use of economic tools. ${ }^{30}$

Following the promulgation of the OPA rules in 1996, the lack of a focus on restoration-based approaches to valuation of interim losses under CERCLA emerged as a concern within the NRD community, and in December 2005, DOI convened a federal advisory committee, comprised of a diverse group of interested stakeholders, to consider the

by $\$ 990.27(a)(2)$ of this part, trustees may estimate the dollar value of the lost services and select the scale of the restoration action that has a cost equivalent to the lost value").

28 These regulatory obstacles to the trustees' reliance on stated-preference methods may also apply to NRD categories beyond "non-use" including recreational losses.

29 See, for example, Letter from Brian D. Israel to Craig O'Connor, dated February 8, 2012 ("Only after determining that such scaling methods are inappropriate may the Trustees turn to valuation methods. To our knowledge, the Trustees have not made any of the determinations necessary to justify their current assessment proposal. Accordingly, the regulatory conditions precedent have not been satisfied, and the Trustees are not properly following their own legal framework").

30 Note also that there is some case law regarding prior versions of the CERCLA rules that treats economic valuation of interim damages and compensation of non-use values favorably. In Ohio, 880 F.2d 432, which was a challenge to the rules promulgated in 1986 and amended in 1988, the court upheld DOI's inclusion of CV as a method that could be used to estimate use and non-use values. It also struck down DOI's rule that option and existence values be estimated in lieu of use values only when use values cannot be determined, finding instead that "[o]ption and existence values may represent 'passive' use, but they nonetheless reflect utility derived by humans from a resource, and thus, prima facie, ought to be included in a damage assessment." Id. at 464 (citing Cross, F.B., 1989, "Natural resource damage valuation," Vanderbilt Law Review, 42(269), 285-9). 
issue. A key recommendation of this advisory committee was that DOI should seek to conform the CERCLA regulations with the OPA regulations and undertake, without delay, a targeted revision to emphasize restoration over monetary damages. DOI undertook to implement this recommendation and in 2008 promulgated amendments to the rules. The new regulations, which are the version currently in effect, provide the option for a restoration-based approach to all damages, including use and non-use interim losses. The Federal Register notice issued by DOI in connection with the revisions expresses a clear preference for this approach: "Methodologies that compare losses arising from resource injury to gains expected from restoration actions are frequently simpler and more transparent than methodologies used to measure the economic value of losses." 31

\section{THE TRUSTEES THEMSELVES PREFER TO AVOID CONTINGENT VALUATION METHODS}

While economists and others have debated the validity and reliability of survey valuation methods, the government itself rarely relies upon such studies in NRD cases. To our knowledge, NOAA, for example, has never used survey methods to measure non-use damages under OPA.

Perhaps the most instructive example of the government's reluctance to rely on CV methods involved the Deepwater Horizon oil spill that occurred in the Gulf of Mexico in 2010. Injury from that incident was eventually assessed in a document called the Deepwater Horizon Oil Spill: Final Programmatic Damage Assessment and Restoration Plan and Final Programmatic Environmental Impact Statement ("Deepwater PDARP”), prepared on behalf of multiple federal agencies as well as agencies of the states of Texas, Louisiana, Mississippi, Alabama, and Florida (the "Deepwater Horizon Trustees"). ${ }^{32}$ Initially, the Deepwater Horizon Trustees had commissioned multiple in-depth surveys designed to estimate the lost use and non-use values resulting from the spill. BP Exploration \& Production Inc. ("BP"), one of the responsible parties for the incident, challenged the Trustees' decision to undertake these studies and, despite agreeing to perform a cooperative assessment and fund much of the Deepwater Horizon Trustees' investigation, refused to fund the non-use

31 Natural Resource Damages for Hazardous Substances, 73 Fed. Reg. 57, 259 (Oct. 2, 2008) (to be codified at 43 C.F.R. pt. 11), accessed December 10, 2016 at https://www.gpo.gov/ fdsys/pkg/FR-2008-10-02/html/E8-23225.htm.

32 Accessed December 10, 2016 at http://www.gulfspillrestoration.noaa.gov/restorationplanning/gulf-plan/. 
surveys before the Trustees had made a formal determination, as required by the OPA regulations, that in-kind restoration or scaled restoration was inappropriate.$^{33}$ Ultimately, the damage assessment set forth in the Deepwater Horizon PDARP relied on none of the stated preference surveys regarding the dollar value of injured habitat and wildlife. Instead, the Trustees used a restoration approach, setting forth a comprehensive restoration plan for both use and non-use alleged damages.

During the public comment period after the release of the Draft Deepwater Horizon PDARP, multiple commenters asserted that the PDARP was incomplete because it failed to value ecosystem services through CV surveys. The Trustees responded by stating that:

The commenter is correct that the Trustees did not use a CV approach to value ecosystem services here, but the commenter's proposed approach is not required by law or regulations. In fact, the Oil Pollution Act regulations contain a clear preference for basing the amount of natural resource damages sought from the responsible parties on the costs of implementing a restoration plan that would repair or replace injured natural resources where practicable and compensate the public for interim losses of natural resource and ecosystem services until the ecosystem has fully recovered. That is the primary approach to damage assessment that the Trustees adopted in response to the Deepwater Horizon spill and the basis for the preparation of this PDARP/PEIS. . The Trustees performed a CV total value study for the Deepwater Horizon incident. However, because the Trustees concluded that natural resource injuries and ecosystem service losses in this case can be addressed by the preferred ecosystem-wide restoration alternative described in the Final PDARP/PEIS, the Trustees did not complete that study and did not rely on it. ${ }^{34}$

The fact that CV surveys were considered and rejected for the Deepwater Horizon incident is particularly significant in light of the diverse and sensitive resources that the Trustees asserted had been injured. According to the Trustees, the incident was "the largest offshore oil spill in the history of the United States," which "injured natural resources as diverse as deepsea coral, fish and shellfish, productive wetland habitats, sandy beaches, birds, endangered sea turtles, and protected marine life." 35 The Trustees also concluded that "[t]he oil spill prevented people from fishing, going to

33 See document in Footnote 32.

34 Deepwater Horizon Trustees (2016), "8. Trustee responses to public comments on the draft PDARP/PEIS," Deepwater PDARP, pp. 8-21 to 8-22, accessed December 10, 2016 at http://www.gulfspillrestoration.noaa.gov/wp-content/uploads/Chapter-8_TrusteeResponses-to-Public-Comments_508.pdf [emphasis added].

35 Deepwater Horizon Trustees (2016), "1: Introduction and Executive Summary," Deepwater PDARP, pp. 1-3, accessed December 10, 2016 at http://www.gulfspillrestoration. noaa.gov/wp-content/uploads/Front-Matter-and-Chapter-1_Introduction-and-ExecutiveSummary_508.pdf. 
the beach, and enjoying their typical recreational activities along the Gulf of Mexico." ${ }^{36}$ Given that a restoration-based approach can effectively be applied to this varied range of injuries, including resources as unique as endangered and protected species, and resources as difficult to restore as deep-sea coral, it is difficult to identify any scenario where a CV approach would be appropriate.

\section{TRUSTEES SHOULD ABANDON CONTINGENT VALUATION AND SIMILAR METHODS AS A MATTER OF POLICY}

As we have demonstrated above, there are enormous - possibly insurmountable - legal obstacles to the use of survey valuation methods for measuring non-use damages in environmental litigation. These methods are highly disfavored by the relevant regulatory structures. These methods have been rejected or disregarded by the courts. And, since the Montrose decision nearly two decades ago, these methods are generally shunned by the very government trustees responsible for implementing the NRD program in our country.

Despite this legal landscape, and despite the extensive econometric hurdles presented in this book, some economists continue to advocate for the use of $\mathrm{CV}$ as a viable method for capturing non-use value.

There are at least two additional policy reasons why trustee agencies should abandon CV methods and focus instead on capturing non-use values through restoration. First, CV methods are extraordinarily expensive. The CV studies conducted in Montrose, Exxon Valdez and Deepwater Horizon cost tens of millions of dollars. Given that in no case have these studies actually worked, it is hard to justify the cost. ${ }^{37}$ In Deepwater Horizon - perhaps the most complicated, wide-ranging NRD assessment ever undertaken - the trustees spent millions of dollars on a CV study and, in the end, concluded it was not necessary or appropriate to rely upon that study. If a restoration-based assessment approach is viable in the case of alleged impacts across the entire northern Gulf of Mexico, it is hard to imagine any plausible scenario where a restoration-based approach would be inappropriate.

36 Id.

37 Indeed, under the CERCLA regulations, NRD assessment costs are not considered reasonable, and thus are not recoverable, if "the anticipated increment of extra benefits in terms of the precision or accuracy of estimates obtained by using a more costly. . .methodology are greater than the anticipated increment of extra costs of that methodology," $43 \mathrm{CFR}$ $\S 11.14$. 
Finally, CV and other survey methods rest upon a flawed premise. The governmental agencies charged with assessing and restoring damages (i.e., natural resource trustees) have extensive information about the real cost of protecting and restoring natural resources, gained through their work on other NRD cases and their work to manage natural resources in national and state parks, forests, seashores, fisheries, and other public lands and waters. Agencies rely on that information and their experience to identify the actual cost of work to protect, restore, and expand these resources on a daily basis. But when they instead rely on the results of stated preference surveys in assessing damages, the trustees willingly step aside and instead rely upon a randomly selected sample of the public to assign a dollar value to these resources.

The supposed rationale for relying upon a public survey is that the public has suffered a loss and, as such, only the public can measure the value of that loss. But that rationale does not apply in other environmental contexts. For comparison, in the case of environmental risk from industrial activities, no one would ever think to use a survey of randomly selected members of the public to determine the levels of contaminants that present a risk to human health and the environment. Instead, we routinely rely upon scientists, economists, and other experts to make those judgments based on data and analysis. Likewise, with the valuation of damages resulting from a pollution event, the better approach for measuring such damages is for experts (not a group of randomly selected members of the public) to determine how much restoration is required to return natural resources to baseline conditions and to compensate for the interim losses. Fortunately, the NRD jurisprudence, regulations, and precedent all point to exactly that outcome. 